\title{
Um estudo histórico-filosófico do ensino de fundamentos de Cálculo para licenciaturas da área de exatas
}

\section{Talles Trama Buozzi*, Alexandrina Monteiro.}

\begin{abstract}
Resumo
Tendo em vista que a disciplina de cálculo I está presente em diversos cursos do ensino superior e os elevados índices de reprovação que podem ser observados nesta disciplina, tornou-se importante analisar as principais justificativas apresentadas por pesquisadores da área da educação e da matemática, as quais em sua maioria apontam para a má formação do estudante ingressante. Após as análises de tais justificativas, passamos a analisar e comparar o currículo do ensino médio, por meio de documentos oficiais e de livros didáticos, com os pré-requisitos necessários para cursar cálculo I.
\end{abstract}

\section{Palavras-chave: \\ Currículo, filosofia da matemática, história da matemática.}

\section{Introdução}

Frente ao grave problema de reprovação na disciplina de cálculo I nas universidades brasileiras, procurar causas, justificativas e soluções se torna uma atividade importante. Procurar formas outras de se ensinar, pesquisar disciplinas pensadas pelas instituições e opiniões de profissionais da área da educação podem direcionar na busca da compreensão de como lidar com a reprovação.

Podemos encontrar duas justificativas mais comuns para este problema, são elas: o "dom nato" e a falta de base dos alunos. Tais justificativas seguem no sentido de naturalizar as reprovações e não questionar as formas de ensino das universidades.

Como forma de aprofundar este debate, analisamos os principais documentos que regulamentam o currículo do ensino médio e as pontuações alcançadas em matemática pelos alunos no Pisa e no Enem.

\section{Resultados e Discussão}

A reprovação em cálculo I é um grave problema pelo qual muitos estudantes da área de exatas passam durante a vida universitária, isto pode acarretar em transtornos psicológicos e evasão entre os alunos. Diante disso, buscamos discutir as causas dos altos índices de reprovação, pesquisando as justificativas mais recorrentes entre os profissionais da área. Cruz (2006) aponta que a competitividade dentro das instituições de ensino superior pode se tornar uma ferramenta de exclusão social.

Como forma de justificar os índices lemos coisas como o "dom nato", segundo o qual o sucesso em matemática está relacionado à genética do indivíduo, e o problema de falta de base dos estudantes, dizendo que o aluno terá dificuldade em cálculo pois não teve uma boa educação básica.

Estas justificativas tendem a naturalizar as reprovações, transferindo a responsabilidade da instituição para alunos e professores, evitando, dessa forma, pensar novas propostas de ensino que promovessem uma melhoria no ensino.
Como forma de aprofundar este debate, passamos a buscar em documentos oficiais os conteúdos do ensino médio e comparar com o que se ensina nas disciplinas de pré-cálculo. Considerando que a institucionalização dessa disciplina pode vir a atender as dificuldades dos alunos em Cálculo I, uma vez que é necessário considerar as diversas adversidades presentes na educação básica brasileira. Mas, também entendemos que é necessário repensar a abordagem e o programam de cálculo I, o que demandaria uma nova pesquisa.

Por fim, a análise da proposta indicada no texto da BNCC e ainda considerando-se a história da formação deste documento, entendemos que o papel e a proposta da educação básica na formação do estudante apresenta seus reflexos no ensino superior o qual também precisa ser repensado.

\section{Conclusão}

O problema da reprovação em cálculo I é importante e deve ser questionado no sentido de tentar entender suas causas e buscar modos outros de se desenvolver esta disciplina.

Encontramos, geralmente, justificativas que promovem o problema da exclusão social, as quais devem ser problematizadas, através de dados e de documentos oficiais que regularizam a educação brasileira.

Agradecimentos
$\begin{aligned} & \text { Agradeço ao SAE-Unicamp/PIBIC pelo fomento à } \\ & \text { pesquisa }\end{aligned}$

BRASIL. Base Nacional Comum Curricular: Ensino Médio. Brasília: MEC/Secretaria de Educação Básica, 2018

Cruz, F. (2006) Expressões e significados do fracasso escolar em matemática: representações sociais de professores e alunos da educação básica e do ensino superior. Tese de Doutorado em Educação, Programa de Pós-Graduação em Educação, Universidade Federal de Pernambuco, Recife 